\title{
Vital Geographies: Life, Luck, and the Human Condition
}

\author{
Gerry Kearns* and Simon Reid-Henry ${ }^{\dagger}$ \\ *School of Public and International Affairs, Virginia Polytechnic and State University \\ †Department of Geography, Queen Mary, University of London
}

\begin{abstract}
Life has been problematized anew by recent social change and scientific innovation. There are important and little studied geographical dimensions to any such understanding of "the politics of life itself," however. A geographical perspective involves, first, highlighting the spatial aspects of both states and capital, two rather neglected dimensions of vital politics. Elaborating the geographical constitution of vital politics entails further describing the related powers of knowledges and practices. Reflecting on the geographical dimensions of longevity and health leads directly to a recognition of the ethical implications of the geographical luck of birth and residence. Taking up this ethical challenge requires specifying at least six components of geographical justice: culpability, fairness, care, state failure, human rights, and solidarity with environmental and social justice. Key Words: biomedicine, care, health, inequality, justice, longevity, medical ethics.
\end{abstract}

最近的社会变革和科技创新给生活提出了新的问题。对 “生活本身的政治性” 这一问题的理解, 有一些重要的地 理方面的研究, 但是却很少。地理方面研究所涉及的角度包括: 首先, 突出了国家和资本的空间属性, 这是重要 政治研究里被忽视的两个方面。对重要政治的地理成分进行详细阐述可以引起进一步强化说明知识和实践的相关 力量。长寿和健康情况的地理分布属性直接导致对下述伦理命题的承认, 即出生和居住地的地理运气。接受这一 伦理挑战, 需要至少六个具体的地理公正成分：罪责，公平，护理，国家失败，人权，环境和社会正义的团结。 关键词：生物医学，护理，保健，不平等，司法，长寿，医疗道德。

Otra vez, la vida adquiere dimensión problémica en virtud del cambio social y la innovación científica. Sin embargo, aunque existen importantes dimensiones geográficas para comprender "las políticas de la vida misma," muy escaso es el estudio hecho sobre el particular. Una perspectiva geográfica a este respecto implica, primero que todo, destacar los aspectos espaciales tanto de los estados como de sus capitales, dos expresiones de las políticas vitales hasta ahora muy marginadas. Elaborar la constitución geográfica de la política vital demanda describir con mayor profundidad los poderes relacionados de conocimientos y prácticas. El reflexionar sobre las dimensiones geográficas de longevidad y salud lleva directamente a un reconocimiento de las implicaciones éticas de la casualidad geográfica del lugar de nacimiento y residencia. Para asumir estos retos éticos se requiere especificar por lo menos seis componentes de justicia geográfica: culpabilidad, equidad, cuidado, falla del estado, derechos humanos y solidaridad con la justicia ambiental y social. Palabras clave: biomedicina, cuidado, salud, desigualdad, justicia, longevidad, ética médica.

$\mathrm{L}$

ife is being politicized in new and novel ways today, especially in Western societies and especially with regard to some of the possibilities wrought by recent and rapid developments in the biological sciences. A growing number of geographers, anthropologists, and sociologists are exploring such "vital" issues as the social implications of neuroscience or the political and legal vortex surrounding regenerative medicine (Fischer 2003; N. Brown and Webster 2004; Wainwright et al. 2006). So, too, are they analyzing how life is being revalued (Collier and Ong 2005; Sunder Rajan 2006; Waldby and Mitchell 2007). Such nonphilosophical accounts of the politics of life (that is, accounts that are based primarily on ethnographic or sociological investigation rather than on a purely philosophical reflection) concern what we might call the form of life itself and how various technologies reconfigure it. Such work constitutes a sociology of possibility.

The emphasis of a sociology of possibility on advanced biomedical technologies, although it might offer a readily available means for theoretical reflection on the nature of being human, does not provide either a particularly representative account of the politicization of human life today (except for a minority elite within the West) nor does it broach what are arguably the most politically and ethically pressing questions concerning 
the politics of life for the majority of the world's population. Possibilities are not everywhere and for all people the same, of course. There are also some basic geographical questions one might ask about the way "life itself" is politicized today.

These questions turn less on the possibilities opened up by new technologies and more on the problems of their uneven distribution, because, clearly, rather less novel and more mundane material inequalities exist alongside (and in some cases they are being reshaped by) the technological developments that preoccupy much of the recent literature on the politics of human life. In this article we therefore want to sketch out an analysis of the politics of life that starts with the most basic problems of inequality in life chances and the broader structural conditions in which life chances are shaped (Benatar, Daar, and Singer 2003).

Our argument develops over five parts. First, we offer a critique of some of the recent work on vital politics, asserting in particular the need to pay greater attention to states and capital when thinking about vital politics. We then suggest ways in which thinking about the geographical constitution of vital knowledge and vital practices helps to reincorporate these elements and better frames our present capacity not only to make live but also to let die. In the third part, we examine in more detail what we consider to be the most pressing feature of these geographical dimensions of vitality, the geography of longevity (or "geographical luck"). We further correlate this notion of geographical luck with an analysis of geographical justice, then conclude by noting six basic vital geographies: culpability, fairness, the ethics of care, state failure, human rights, and the global social and environmental justice movement.

\section{Vital Politics}

Human life has its limits in birth and death. To live is to be able to make things happen by free will; things that would not occur without our having desired them, would not occur purely by what Kant termed "mechanism" (Kant [1790] 1911, 7). We might follow P. Patton (1989) and Diprose (1995) in appropriating Berlin's (1958) concept of "positive freedom" to describe this dimension of our being-in-the-world, but Berlin's depiction of life as capacity is limited. Life should also be thought of as potential. It can be developed, realized, squandered, used up, or lost. Vital geographies might explore this twofold sense of life, as limit and as capacity. In both respects, life is subject to cultural, political, economic, and technological imperatives that vary greatly between places and that mean that the question, "What is life?" must ever have a series of geographical answers. This question is raised in a very direct way by recent work on biosociality (Rabinow 1992), the genetic imaginary (Franklin 2000), and vital politics (Rose 2006). There is much to learn from this literature, but we begin by considering some of the ways that the focus on novel science alone might in fact constrain unduly work on the geography of "life itself."

In The Politics of Life Itself, Rose describes what he means by a "vital politics." Set against earlier systems for the management of life, "the vital politics of our own century looks rather different," because, argues Rose, "[i]t is neither delimited by the poles of illness and health, nor focused on eliminating pathology to protect the destiny of the nation. Rather, it is concerned with our growing capacities to control, manage, engineer, reshape, and modulate the very vital capacities of human beings as living creatures" (Rose 2006, 3). Rose proposes that recent developments in the biological sciences mean that "life itself" is currently being refigured not at the organic but at the molecular level. The technological capacities of genetic engineering open up for some people the possibility of optimizing their period of healthy life: a "prospect" that might, in turn, impose on them an obligation to avail themselves of this monitoring. The ethical significance of the creation and disposition of vitality, he proposes, will increasingly draw citizens into engagement with professional bioethicists. In place of biopolitics, Rose posits an emergent era of "ethopolitics" in which responsibility for the management, shaping, and conduct of vital capacities are, like many other things, being devolved from the state into the private realm of citizens' own desires and responsibilities.

There is much to admire in this account of a new vital politics, but we would point to the additional value in thinking of life as limit and capacity on the basis of three basic points. First, and as Rose would likely be the first to acknowledge, the account of the politics of life itself that we have to date is one centered largely on the advanced liberal democracies. A more geographically inclusive account, however, would help to unsettle certain of the Western norms that have become the focus of much debate in this literature. Braun (2007) has recently argued, for example, that many of the medical technologies that Rose discusses are beyond the financial reach of the vast majority of people living. This is not to say we should not document the inevitable geographies of technological transfer and adaptation of these technologies (Reid-Henry forthcoming) but it is to acknowledge that vital politics take various forms 
that might often be quite removed from considerations of technology. As Daniels $(1985, \mathrm{x})$ has argued, from a philosophical perspective, although "the more dramatic topics of abortion, euthanasia, and organ transplantation [seem] to hog the philosophical stage," these might not feature as prominently if the focus were instead on designing a just health care system. Benatar $(2003,389)$ notes a related individualism in medical ethics: "[t]he understandable focus on ethical issues at the interpersonal level has undoubtedly eclipsed ethical issues that need to be addressed in dealing with [broader] public health issues."

A related point concerns how one approaches technology. Given that the stated interest of much recent work on vital politics is to consider how definitions and treatments of life are changing, it makes sense to focus on new technological (invariably biomedical) developments, where such definitions might indeed be being actively reworked. Any work seeking to understand society through the lens of biomedicine, however, privileges shifts in the concepts of life and practices made with regard to life in the domain of possibility. There is a danger that such an approach might ignore the politics of life in more mundane settings. Rose argues, for example, that in the past eugenics was about trying to control the reproduction of undesirables so that the next generation would come from the fittest members of the current generation. Now, he suggests, the new technologies of reproduction give to couples, and not the state, the decision about whether, given various probabilities of particular biological outcomes, they wish to proceed and give life to a fetus. This is an extremely interesting development, but it seems wrong to suggest that such novel and privatized determinations of life are anything like as ubiquitous as the regulations of life's limits and capacities wrought by states and capital.

This gives rise to the third point on which we diverge from Rose's account. In place of an emphasis on emergent and technologically derived choices (and their attendant responsibilities), we would emphasize the relationship between individual autonomy and political-economic structures. Consideration of the role of states and capital is crucial here, for both also work to (re)constitute vital limits and capacities. States have long licensed the use of human capacity through various employment laws, and capital has long been the arbiter of human vulnerability in terms of class, ethnicity, gender, and location (Rapp 1999; Farmer 2004). To reduce biological risk, as Rose does, to nothing more than the likelihood of disability or illness as it confronts the individual is to underestimate greatly how human biophysical existence is directly politicized by states and capital (Petryna, Lakoff, and Kleinman 2006). From the geography of capital punishment, to the management of world hunger, to the denial of medical supplies to countries blockaded for ideological reasons, vital geographies should begin with questions of states and capital because these structure the life chances that confront different individuals. As a way of framing how it might do so, we first consider some aspects of the relationship between these sorts of geographies and human vitality.

\section{Geographies of Life}

Human vitality is structured by geographically mediated inequalities: patterns of life chances that, although they might be locally articulated, are connected to events elsewhere. At its crudest, this means that the value of life in some places is predicated on the nonvalue of life elsewhere. Most usually, of course, such a geography is multifaceted and complex, but it is worth signaling three persistent and interconnected dynamics that in various ways might be said to frame the sort of vital politics Rose and others are concerned with but also provide a platform for developing a rather different critical account thereof. First, we briefly consider how the production of knowledge about life is bound up with the production of geographical knowledge more broadly; second, we examine how attempts to mobilize or deploy this knowledge, or to give social meaning and value to it, are taken up in existing struggles over space; third, we sketch out some of the ways in which these emergent vital orders are themselves creating new geographical conditions for life itself.

\section{Vital Discourses}

The life sciences allow us to conceive of life in certain ways. They do indeed constitute a foundational epistemology of modern life, evident in the "avalanche of printed numbers" (Hacking 1982) corralled in the name of civilizing public health in the nineteenth century (Craddock 2000) and one still apparent today. Speaking of genomics, Sunder Rajan $(2006,14)$ suggests that "the sorts of knowledge genomics provides allows us to grammatically conceive of life in certain ways, not in terms of Aristotelian poesis, but rather as that whose futures we can calculate in terms of probabilities of certain disease events happening." This is true for some people, but why it is not true for others is a question less often asked in the posthumanist literature on the social implications of the contemporary life sciences. Geography 
is part of the answer and particularly in a recognition that these knowledges-specifically the ability to know disease events as calculable risks - are produced and circulate within circumscribed spaces (see, for example, Hall 2004).

How we know the world is constitutive of how we come to know ourselves as biophysical beings. The history of Western knowledge of the self is in part the history of knowledge of the body, of course, but the body in question has always been understood through a distinctively geographical lens and in some ways continues to be so (for an interesting account of how Western and non-Western conceptions of bodies and medicine can coexist, see Del Casino 2004). From Plato's attempt to connect the care of the body to the care of the soul in his Timaeus (Phillips 1987; Rabinow 1999) to the rites of passage that marked social death for undesirables (such as lepers) in the Middle Ages (Brody 1974), to know the body was to treat the body in accordance with broader cosmologies or worldviews (for a modern example, see Renzaho 2004). The same applies throughout modern history (Martin 1992). Imperial worldviews were inscribed on the bodies of slaves (Quinlan 1996), and the mad were confined to ensure dominant perceptions of social life as sane and rational accorded with the world they sought to describe (Philo 2004). Discourses of life, then, are produced locally but in concert with broader imaginations of the world. Modern medicine was stimulated by the challenges of urban growth (Hardy 1993) and animal husbandry (L. Wilkinson 1992; Swabe 1999) as they either presented ecological niches for disease or introduced new pathogens into a suitable pool of hosts.

Contemporary biomedicine is likewise locatable within this historical and geographical matrix. One of contemporary biomedicine's defining features is that it is produced within increasingly sanctioned institutions (the hospital, the laboratory, and so on) at the same time as it continues to seek a universal ambit: It tends to present as universal a conception of the body that is in fact a product of its own (in part spatial) operations. This ascription of universality resists the validity, even existence, of alternative framings of bodies and capacities, as in rival cosmologies. ${ }^{1}$ When we take biomedicine as our principal referent for contemporary vital politics, we thus in part occlude the historical attempt to universalize and privilege a particular sort of body-knowledge and the power relations that pertain to it (Scheper-Hughes and Lock 1987). Instead, it should be possible to consider biomedicine in the context of the imperial (Bell, Brown, and Faire 2006) and other histories that have helped it to appropriate a universal referent through which it has marginalized other bodies and knowledges and against which it has been formed (Arnold 1994; Anderson 2004) and to consider this attempt itself in comparative perspective (Lock 2002; Lakoff 2005).

Just as our knowledge of the world has shaped biomedical knowledge, we must also remember that medicine's own worldview has helped to construct the world in that image. Whether it be city planners drawing on models of circulation (Sennett 1996) or computer malfunctions that are today described and treated as "viruses," our knowledge of bodies and their biological processes has a pervasive influence on the way we organize our world (Martin 1987; Treichler 1999; Thacker 2003). Canguilhem ([1966] 1991) writes of the historical formation of concepts of normal and pathological in modern medicine (Philo 2007), but we might also take from his analysis that it is in these crossings between medical knowledge of the body and geographical knowledge of societies that many such political determinations arise. This much was evident in the national stereotyping of syphilis (as the Spanish disease for the Dutch, the "French Pox" for the English, and so on; Porter 1997, 166), and it is evident today. King (2002), for example, compares the emerging diseases worldview with colonial-era ideologies of public health to show how on the basis of particular geographical imaginations the latest understandings of health could be mobilized to serve much wider political-economic agendas (Ingram 2007). Perhaps the most significant contemporary manifestation of this discourse, though, is that of biosecurity. Braun (2007) proposes that we consider the current mantra of biosecurity as itself related to the emergence of a geopolitics of interventionism and extraterritoriality. Discourses of biosecurity echo an imperial geopolitics that justifies defending the homeland by preemptively intervening in foreign countries. For example, in the name of security, rich states anticipate controlling their own exposure to a humanized version of bird flu by public health interventions in Vietnamese villages.

This is a pertinent point and we raise a not dissimilar one later. For now, though, we simply want to suggest that arguments that point to the radical openness of new technologies can be readily coopted by politics that seek to use technologically mediated threats to justify the expansion of sovereign powers abroad. In the case of bird flu, attention might thus be better focused on the political ecologies of human-bird relations, such as are described in Davis's (2005) account. His story is every 
bit as apocalyptic as many biosecurity discourses but the practices he implicates are those of commercialized agriculture rather than the production of novel life forms. Focusing not on the radical openness of possibilities but on the often quite structurally closed probabilities of a global ethics tied to the capitalist imperative, would draw our attention here, as it draws the attention of Davis, to the explosion of meat consumption (particularly poultry) in the slum cities of the world, which has produced a new ecology of human-animal proximity. The use of antibiotics as prophylaxis to maintain chicken weight has produced a dangerous soup in which viruses will mutate and jump species. The unregulated movement of live birds within the corporate agricultural sector links third-world cities to factory farms in richer countries, where the promiscuous use of antibiotics is extreme and dangerous. The risks are evident and human influenza has probably always been generated in such "agricultural" settings. The focus of our attention should thus be on the care of the birds, rather than on novel science. Bird care is the heart of the problem, and in bio-care, rather than biosecurity, lies the solution.

Finally, it is useful to consider how discourses of life and geographical discourses are, in certain important regards, mutually constitutive. One cannot account for the peculiar power of biomedical knowledge without accounting for the ways that it has also worked to erase certain geographical differences. Medical research that accepts race as a reporting category, for example, can imply that the differences between races have to do with biological inheritance and are not, say, a consequence of geographical origins or patterns of endogamy (Epstein 2004). Lifestyle factors that depend in part on poverty could well influence health, but social groups have to submit to a form of ethnic medicalization to get attention from medical research sponsored by the U.S. Food and Drug Administration (FDA). Drug testing in the United States tended to use all-male cohorts of college students to test the efficacy and safety of drugs, but then approve those drugs for use in all populations. To get women added to drug testing programs in 1993, the argument used was that women are biologically different from men (Epstein 2003). In figuring such differences between men and women as biological, however, such arguments address, as Epstein (2003) points out, neither nonbiological causes of ill health (violence, stress, poverty) nor the nonmedical dimensions of the failure of health care for women (the sexism, patriarchy, and ignorance of some medical professionals). Pertinent differences are too often understood as rooted in biology and not in social or geographical context.

\section{Vital Orders}

It also warrants considering how attempts to mobilize or deploy vital knowledge or to give social meaning and value to it are taken up in broader attempts at spatial control or ordering according to particular logics (T. Brown 2000). We need to understand this point if we figure on developing accounts of how and why human vitality is politicized in ways that might be connected but not limited to the technological. Again, there seem to be two countervailing tendencies here. On the one hand, the deployment of vital knowledge (whether in the form of long available basic health statistics or new genetic testing kits) gives expression also to the rationalities by which such knowledge was produced (Lakoff 2005; Hacking 2006). If life was once "inserted into history," as Foucault famously declared, we might now say that the constant reinvention of ways in which that insertion can take place has now itself become a specific logic of power (Clarke et al. 2003). The "interpretive gaze" of bioethicists and statistical experts, for example, is organized according to particular prior worldviews and in turn the vital information they accrue is deployed within already existing social domains (Benatar 2005). Innovation at one end of the spectrum can thus be devastation at the other, with priority setting, the introduction of new "standards," and the like demanding more in theory than can always be delivered in practice and often drawing both attention and resources away from the major issue.

Consider, for example, the take-up of the disability adjusted life year (DALY) by the World Bank. The DALY is a measure that considers potential years of life lost due to premature death alongside equivalent years of "healthy" life lost by virtue of being in states of poor health or disability (Murray and Lopez 1996). The DALY measure is one of the few explicit attempts to put a quantifiable value not only on living and dying (as mortality and morbidity statistics seek to do) but also to place value on life that is lived with disease (Bond 1999). According to the World Health Organization (WHO 2007), "[o]ne DALY can be thought of as one lost year of 'healthy' life and the burden of disease as a measurement of the gap between current health status and an ideal situation where everyone lives into old age free of disease and disability." The underlying assumptions of the DALY, however-a measure introduced by Western statisticians or biometricians-are that the burden of disease is felt equally in all countries. If we think of a condition such as paraplegia, however, 
it soon becomes clear that such a condition is more "severe" (even for what clinically is an equally severe condition) in a poor country context in which scant resources will, and social values might, add to the more narrowly "biological" disabilities of the condition. As Allotey et al. $(2003,949)$ say, DALYs thus "risk exacerbating inequalities by undervaluing the burden of disease in less-developed countries." They also contribute to an individualization of health that has nothing to do with "choice" (as Rose argues) and everything to do with the upscaling of Western values and in particular a concern with whether health interventions are cost-effective, rather than with their equitability. The DALY was a principal measure informing the WHO's Global Burden of Disease Surveys, which are intended to inform macroscale health decision making over the next few decades (J. Cohen 2000; Arnesen and Kapiriri 2004).

Such vital orders are not just created in and of themselves. They must also be operationalized, which also involves particular sorts of spatial ordering and control. It has long been recognized that the reorganization of space at various levels (international, national, and urban) constructs niches of biological vulnerability. The current crisis in Darfur bears witness to this relationship between dislocation and disease vulnerability. So, too, does the confinement of individuals in place also shape their social position and vulnerability, not only to disease but to the interventions of biomedicine itself. Thus, infamously, in Tuskegee, Alabama, African-American subjects were recruited, from 1932, to a study of untreated syphilis that continued until 1972, a quartercentury after their condition might have been treated with penicillin (J. H. Jones 1981). More benignly, from 1998 to 2004, in collaboration with a private company, the government of Iceland worked to assemble a genetic database intended to comprehend its entire population (Greenhough 2006; Pálsson 2007). Certainly the social marginality and geographical separation of the poor folk of Tuskegee both allowed and hid their abuse (Gamble 1997), and the geographical separateness of Iceland raised the prospects of a fully realized genomic form of governance (Greely 2000). People who can be isolated are attractive for biomedical research. Prisoner populations, for example, have long represented an attractive research population for the way that they are available and located within a relatively stable environment and have historically been used by both government and private organizations (Mitford 1973). Although international and national protections for human research participants now exist (the 1964 Decla- ration of Helsinki and its subsequent revisions, and the U.S. Belmont Commission of 1976 that was prompted by the Tuskegee study, for example), institutional review boards (IRBs) must still nonetheless determine the extent to which a prison population involved in a trial might be subject to either explicit or implicit coercion (such as the possibility for greater social contact by taking part in a trial; National Institutes of Health 1993; Harkness 1996; Wohl 1999).

Finally, it therefore also seems important to consider how individuals are rendered either visible or invisible to the system as their visibility clearly shapes how they are positioned relative to vital knowledge. At a very local level in the United States, for example, in 2004 homeless people accounted for 13 percent of all substance abuse admissions (more than 175,000) recorded in the Treatment Episode Data Set (Substance Abuse and Mental Health Services Administration 2006). Of these, as many as 25 percent would have suffered from severe mental illness. Because most homeless people are only likely to access medical care through emergency services, however, they are effectively screened out from the sort of health care they need. The homeless are particularly vulnerable to such co-occurring disorders (a mental health problem combined with a substance abuse problem) and the difficulties in treating them are compounded by difficulties in physically accessing the homeless (Burrows, Pleace, and Quilgars 1997; North et al. 2004). This is a regional variant of the sort of therapeutic citizenship that Nguyen (2005) has spoken eloquently of at the global level (see, for example, Wilson 2003; Watson et al. 2007; MacKlan 2008). In both cases, however, there is a need to ask what the consequences are of the political regulation and reorganization of space through emergent neoliberal doctrines. In other words, health outcomes are affected as much by the political-economic spatial differentiation of individuals as by the technological mediation of bodies. The two need to be considered together.

This spatialized political-economic differentiation of life is every bit as dynamic and invasive as some of the new medical technologies more frequently discussed in the literature, and is of far more direct concern to far more people around the globe. The words "invasive" and "technology" have relevance here in the broadest possible sense. Consider the "innovation" in various forms of state violence, from incarceration, to murder, to torture associated with the War on Terror. Any discussion of vital politics surely should consider how states intervene in the management of life outside their own borders. In the War on Terror, for example, 
the deployment of certain vital discourses allows some people in certain places to be conceptualized as having lives that simply do not count (Gregory and Pred 2006; Klein 2007). So, too, within the territorial unit of Gaza, the occupying Israeli forces deny the Palestinian residents access to health care, water, food, and employment (Amnesty International et al. 2008). This is a brutal reduction of human life to bare existence as a form of collective punishment for attacks on Israel by some residents of Gaza. Something similar happens in Guantánamo, where deterrence trumps intelligence, and the exemplary punishment of some persons outside the law becomes a spectacular abridging of vital capacity as an expression of a power that aims to terrorize (Foot 2006). This is the power of the torturer to unmake personality to remake a world (Scarry 1985) and medicine is not immune from cooptation (Bloche and Marks 2005). None of these matters really depends on new cientific conceptions stemming from a molecular or submolecular vision of life but they should be taken into account when considering the remaking of human life. One of the most illuminating ways of doing so is to consider how vital discourses and vital orders both get taken up in the management of spatial relations.

\section{Vital Spaces}

We have sketched something of the relationship between vital discourse and geographical discourse and offered some critical reflections on how such discourses flow into the formation and organization of vital orders. In turn, these hierarchies of presumed worthiness translate into distinct geographies of human flourishing. There are identifiable urban geographies of poverty, violence, and abandonment that produce disease and mortality inequalities, as Draus (2004) shows brilliantly for tuberculosis in Chicago and New York and Klinenberg (2002) shows for the Chicago heat wave of 1995. Legal and illegal pharmaceuticals are a singularly important dimension of this spatial shaping of vital opportunity and disadvantage. This process operates as an aspect both of economic opportunity and of individual subjectivation.

The agglomeration of the pharmaceutical industry and the privatization of health care across countries is, as Rose rightly points out, fostering a new bioeconomy with dimensions that are not fully encapsulated by notions of biovalue or by the new forms of material wealth being created and struggled over. There are other ways in which we might consider the bioeconomy, however. In terms of nonlegal pharmaceutical markets, for exam- ple, we might want to consider how the geographical inequalities in New York and the spatial division of the police force under a neoliberalized administration had a lot to do with the location and subsequent management of that city's crack houses. The district of Bushwick, as a case in point, was located at the border of two police districts, both of which left it to the other to police. This result, along with the process of white flight and rent busting that had led many of the properties to be uninhabited, allowed a local drug market to thrive (Friedman et al. 1999). Wallace and Wallace (1998) describe a sort of ecology of neglect within Manhattan that anticipated regeneration in the medium term but that in the short term produced abandoned and fire-damaged houses that served as shooting galleries for people from many different parts of New York City and its suburbs. Such ecologies incubate urban HIV epidemics by shaping needle-sharing opportunities and necessities; the sorts of political economies described earlier then exacerbate them.

These geographies (of economic opportunity for some and the state's neglect of others) have implications for both producers and consumers of pharmaceuticals, both legal and illicit. Within pharmaceutical markets, access to drugs may be determined by geographical resources, say, even as attempts by companies to deal with the fragmented nature of pharmaceutical markets themselves can mean changes in the moral economy of drug production. Some depression drugs are repackaged as anti-anxiety drugs, for instance, owing to the greater market size of the latter (Petryna and Kleinman 2006). So, too, within the drug trade, international circuits of cocaine are shaped by the local geographies of inequality in both New York and Colombia that are essential to its operation.

New subjectivities are also being formed in relation to these geographical processes but these are economic subjectivities as much as political ones. Novas and Rose (2000) identify emergent forms of "biological citizenship" centered on particular biosocial affinities or solidarities and taking the form of various patient action groups and other therapeutic communities. This is novel and interesting but again there are other ways that subjecthood is biologized by the state that actually compromise human capacities. Biehl, for example, proposes that in Brazil under the pressure of neoliberal discourses and policies, the idea of "society" has come to represent that group of efficient persons who can be regulated in the cause of economic productivity; the merely "social," on the other hand, denotes a residuum that a policy of triage discards to a form of 
"social dying" (Biehl 2005, 52). In the service of this politics of triage, troublesome and unproductive family members can be managed as hopeless cases within the family through drugs to achieve "psychopharmical compliance" (Biehl 2005, 22). Later, the person may be consigned to a hospital where overmedication depersonalizes him or her until he or she is sent finally to a hospice, or site of "social abandonment." Although language and desire continue for these people, they now lack the "human-ness" (Biehl 2005, 317) that produces rights. In effect, under neoliberal dispensation, they almost lost that human-ness as soon as they became not only poor but unproductive, too. This is a regulation of life that, producing subjectivities through economic discipline, legitimizes a conflation of "worth exploiting" with "worth letting live."

Of course, the scale at which these affinities may be drawn is an integral part of this sort of biological citizenship. Lawrence Cohen considers the take-up of the family planning operation by Chennai's urban poor. As Cohen describes, the high number of family planning operations undergone by poor women in Chennai is partly explicable in terms of an imperial division between reasoned elites and passionate masses within which nexus the operation becomes a way "to make one's mindful body in accordance with the demands of developmental modernity, to remake one as if one were modern" (L. Cohen 2005, 87). But how do we evaluate this sort of vital knowledge (of surgical procedures) alongside the vital knowledge, say, of the sorts of demographic statistics that have long relocated individuals with respect to the state? How does our account of vital politics change when we consider not only the technologically mediated biopolitics of Cohen's account but also the statistically mediated fertility regime in China (Greenhalgh 2003)? The Chinese reading of Marx's critique of Malthus produced the idea of planned births to replace the anarchy of capitalist human reproduction, yet had the unanticipated consequence that many parents simply hid "illegal" births, producing, as an undocumented residuum, a significant population of unplanned persons beyond the state services central to Chinese citizenship. This unexamined, and yet highly significant, apartheid may have wider consequences even than the sorts of behavioral changes that scholars describe when they treat fertility regimes as processes of subjectivation.

If geographies of scale constitute one axis along which vital spaces past and present have been constructed, geographical variability between places constitutes another. A growing fear among medical experts today, for example, is the tendency toward self-diagnosis that has been encouraged by the ready availability of once hard-to-obtain medicines on the Internet. Diagnoses and the world they diagnose develop in concert with one another (Hacking 1998) and markets for pharmaceuticals develop in response to variously scaled disease niches, often exacerbating inequalities in the global burden of disease, alleviating the burden for some and entrenching it for others. What these emergent pharmaco-politics have in common, however, is that they all work through existing forms of geographical inequality: cutting along lines of race, gender, and class. Not only is inequality linked to the vast differences in drug prices between different places but through forms of patient action in response (again, here we might think of the Treatment Action Campaign in South Africa [Mbali, n.d.] or the Gay Men's Health Crisis in New York [C. Patton 2002]) and responses in turn by the pharmaceutical companies themselves, new arenas of contestation are opening up centered on the very matrices of power through which drugs are connected with bodies within existing political economies. As much as some actors seek to standardize mechanisms of distribution and supply, others (or sometimes the same actors in different places) survive by virtue of destandardization (from peasants buying drugs from street vendors, to the Brazilian state threatening to violate international patent laws to reduce the price of imported antiretrovirals). These differences are crucial to the sort of politics that are emerging.

We are not saying that new developments in biological science have no implications for how we think about human and other forms of life, nor are we saying that these new scientific practices will not have significant geographical dimensions that might be analyzed. We are merely saying that before we focus on novelty alone, we should pay systematic attention to the broader set of questions about life's limits and capacities mentioned earlier and that to do so entails considering how what may well be an emergent set of vital political issues is nonetheless articulated with certain longer standing geographies of life that already structure life chances in very unequal ways (A. Robertson 1998; Marmot 2005). To consider in more detail the nature and importance of such geographies, we now focus on one of the primary dimensions of "vital" inequality: the geography of longevity, or what we call geographical luck.

\section{Geographical Luck}

As we have already outlined, by virtue of social position and the variable distribution of risks and 
resources, people living in different places face highly different levels of public health security, nutrition, and pathogenic challenge. Length of life, in other words, is largely a matter of geographical luck. Given current rates of age-specific mortality, a baby born in Western Europe can expect to live past its mid-seventies, even into its eighties if it is a girl (Kinsella and Gist 1998, 3); however, born in India, the baby could not expect to see its mid-sixties, in South Africa its mid-fifties, and in Uganda its mid-forties. In India, lives are only as long now as those allowed by the mortality rates prevailing in Western Europe in the 1950s, South Africa is equivalent to Western Europe in the 1920s, and people in Uganda are living no longer than Western Europeans during the Industrial Revolution. These differences have something to do with wealth, as shown in Figure 1 (based on UNDP 2005, 219-22, 250-53). No country with a gross domestic product (GDP) per capita above $\$ 20,000$ has an average expectation of life at birth $\left(\mathrm{e}_{0}\right)$ below seventy-seven years but this span of life is also achieved by Chile ( $\$ 10,274$; e 077.9$)$ and Costa Rica ( $\$ 9,606$; e e 78.1) on aggregate average levels of wealth only half this amount and by Cuba on substantially less. There are twenty-six countries with wealth lying between $\$ 10,000$ and $\$ 20,000$ and almost all have life expectancies of about seventy or more, except South Africa (\$10,346; e 049.0$)$ and Equatorial Guinea $\left(\$ 19,780 ; \mathrm{e}_{0} 43.5\right)$, reflecting, in part, the combined effects of AIDS and of unequal income distribution. Sub-Saharan Africa contains all twenty-seven of the countries where with current rates of mortality the average baby could not expect even fifty years of life.

There are, of course, complex and reciprocal relations between wealth and health (Sen 1998) that lie behind these broad national variations but the impact of the levels of mortality found in sub-Saharan Africa on the capacity of the population to provide for itself is rather basic. If adults die so young, they will be

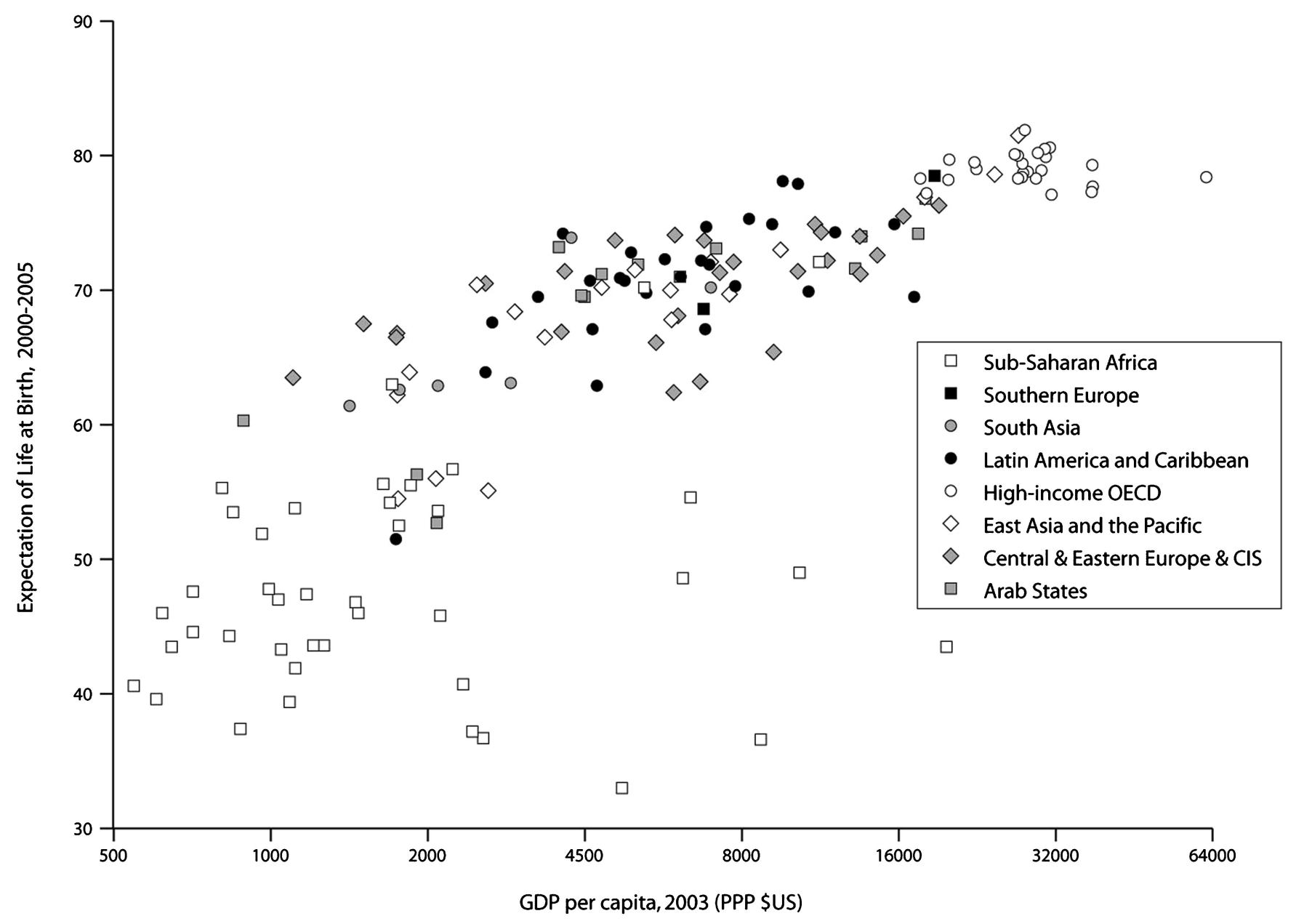

Figure 1. The relation between life expectancy and wealth. OECD = Organisation for Economic Co-operation and Development; CIS $=$ Commonwealth of Independent States; GDP = gross domestic product. 
unlikely to repay the investment embodied in their rearing and education. Some economic historians believe the relations among mortality, dependency ratios, and economic efficiency explain long-term patterns of economic development (E. L. Jones 1981). For still others, the primary controls are environmental and these determine first mortality and thus economic success (Gallup, Sachs, and Mellinger 1999). Yet, these relations are rather more dynamic and the sorts of static correlations between environment and society made within these most basic of vital discourses are of little help here. There are nineteen countries where life expectancy has declined over the past thirty years (see Figure 2). Three of these (Belarus, Ukraine, and the Russian Federation) arose from the break-up of the Soviet Union and the others are all in sub-Saharan Africa. In these two regions, states are increasingly unable to give their citizens the sorts of physical and biological security normally ex- pected elsewhere. The life expectancy in Botswana, at thirty-four, is some thirty-one years below the level the same country had reached by 1988 .

Of course, these sorts of inequalities exist within countries as well as between them. Professional and managerial classes currently make up about 40 percent of the population of England and Wales and unskilled and partly skilled manual workers make up about 25 percent. The gap in life expectancy between these two groups is four years, with the professional and managerial classes having a life expectancy of eighty-two years (Office for National Statistics [ONS] 2006b). This is somewhat less than the equivalent geographical gap in longevity. There are some 8,197 wards in England and Wales that are sufficiently populous to compute a separate expectation of life at birth for the period from 1999 to 2003 (ONS 2006a). The 40 percent of the population living in the healthiest wards has an average

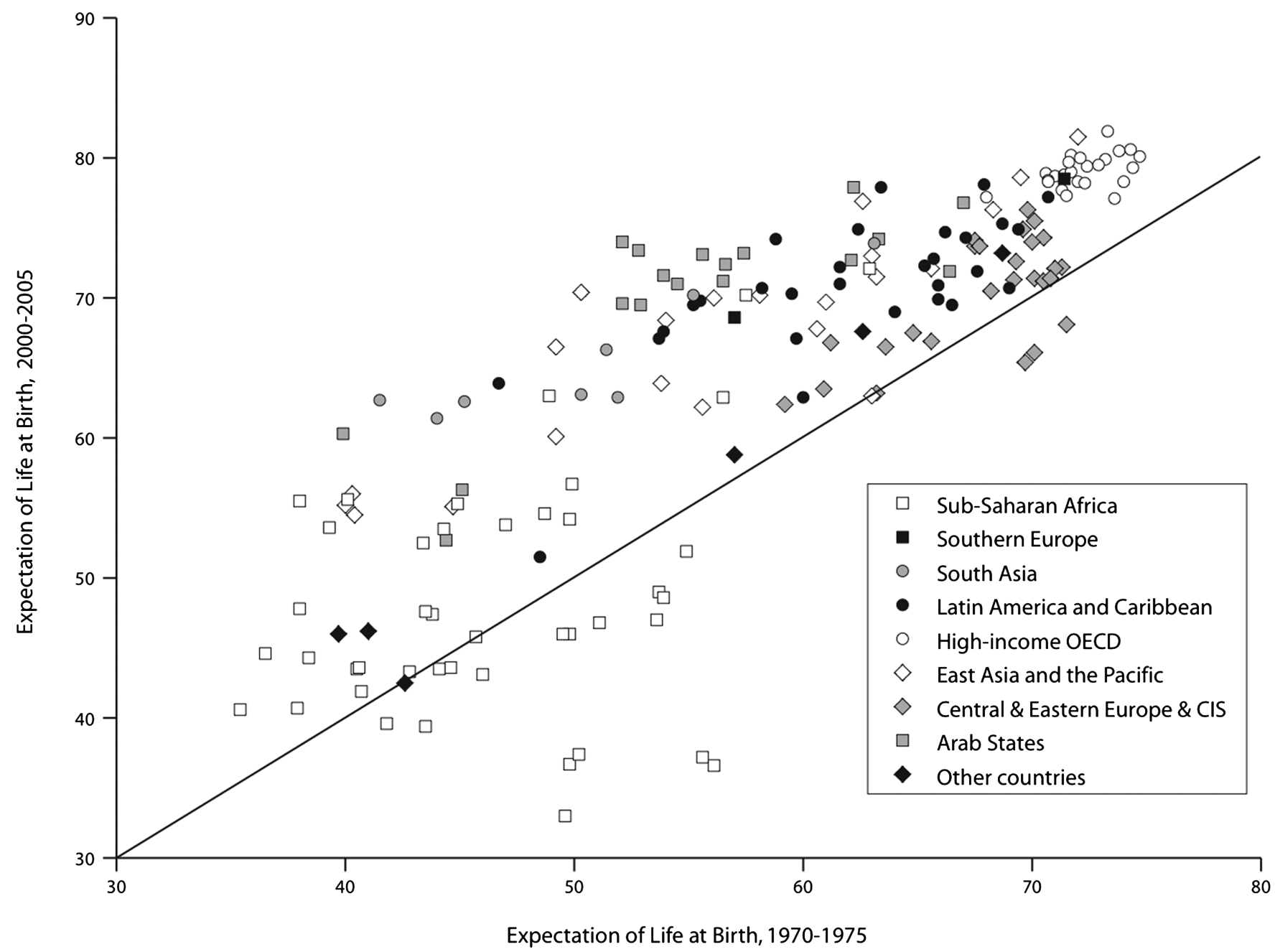

Figure 2. A comparison of life expectancy; 1970-1975 and 2000-2005. OECD = Organisation for Economic Co-operation and Development; CIS $=$ Commonwealth of Independent States. 
expectation of life of 80.9 years, and the 25 percent in the least healthy have only 75.1 years. Place certainly matters and a study of vital geographies should start with this question of what limits capacities.

These relations among health, equality, and geography may be causal and direct. R. G. Wilkinson (1996) has shown that for richer countries (an annual gross national product above $\$ 5,000$ per capita), it is income inequality rather than average levels of income that is better correlated with life expectancy. Similarly, Barnett and Whiteside (2002) propose that unequal societies lack the solidarity needed for effective health care. Wilkinson suggests that egalitarian societies, such as Cuba, put greater social capital into sustaining the well-being of their members and, although some have suggested that this reflects no more than diminishing health returns from greater wealth, it is still an argument in favor of more equality. Even using a weighted sum of class-specific mortalities does not alone explain the differences between states within the United States where there appears to be an additional mortality penalty from living in less egalitarian areas (Wolfson et al. 1999), even for the relatively affluent (Subramanian and Kawachi 2006). It is very difficult to measure the social capital that might account for these differences but some work, again at the level of differences between states within the United States, has demonstrated a strong correlation between income inequality and the degree to which people evince trust in others and, moreover, that when the effect of inequality on trust was accounted for, there was little further statistical variation in mortality explained by the residual pattern of inequality (Kawachi et al. 1997).

Health, wealth, and inequality are interrelated in complex ways, but the global disparities in longevity are so acute that they raise important questions about the nature of our global community, of common humanity. Does the fact that people in, say, Canada, can expect to live for twice the period that people in Botswana can expect place any obligations on the people in Canada? Should the fortunate care for the less fortunate? Have the fortunate any right to their privilege? We turn now to an examination of how and why vital geographies might take up some of these basic observed patterns regarding vital limits and capacities by placing them squarely within a consideration of geographical justice.

\section{Geographical Justice}

The health and mortality advantages some people possess over others are largely unearned. No individual can be said to own them because they are a collective achievement (Kearns 2006). In this way the geographical luck of longevity raises questions of justice, at least on Rawls's (1971) presentation of justice as fairness. Insofar as we recognize ourselves as part of a global community of humans, that is, insofar as we acknowledge the claims of "distant strangers" (Corbridge 1993), we might adapt Rawls's veil of ignorance criterion for the original position so that it refers to geographical rather than social positioning. We might suggest that a fair world, one based on social justice, would be one in which a rational person could afford to be relatively indifferent with regard to his or her place of birth. Such a world would adopt at the global level the principles of justice that Rawls describes. In other words, in the first place, all individuals would have as much freedom as still allows a system of liberty for all other people. In the second place, social and economic inequalities would only be tolerated if they operated to the net benefit of the most disadvantaged members of our world society and if all positions of advantage were equally accessible to people from all locations.

How, then, does the question of the geographical luck of good health and long life look on this reading of justice? Rawls argued that there were certain advantages of birth that were not deserved and that the individual did not, therefore, hold as a property to exploit at will. Fair equality of opportunity might require affirmative action where practicable, and justice might require compensation where affirmative action was not practicable. Extending Rawls's arguments to the field of health, Daniels (1985) suggested that individuals in a fair society had a right to good health, or "normal species functioning." This falls short of the claim of the WHO $(2005,1)$ constitution of 1946 that health is "a state of complete physical, mental and social well being and not merely the absence of disease or infirmity." Although many find this a helpful and expansive understanding of health (Fleuret and Atkinson 2007), we are persuaded more by Daniels, who proposed that this definition of health implies too open-ended a commitment to be helpful as a basis for rights, however useful it might be for other descriptive purposes. In similar fashion, Saracci (1997) suggested that to equate health with happiness is at best vague and, we might add, offers a dangerous prospect of virtually every aspect of our lives being medicalized to the benefit of the pharmaceutical industry (Moynihan, Heath, and Henry 2002), in ways that might actually reduce autonomy and free choice.

Ill health prejudices social inclusion. Social exclusion is also implicated in stress-related conditions (Noh 
et al. 1999) such as drug dependency, hypertension, and mental health problems, including those that provoke suicide (Social Exclusion Unit [SEU] 1999). There is a vicious circle here and research in vital geographies might contribute to debates over primary causes and secondary effects as, for example, in Britain, where the official policy on social exclusion treats children absenting themselves from school as the cause of alienation that, in turn, produces effects through lack of access to jobs and a failure to respect the rights of others (SEU 1999). Truancy is so heavily correlated with poverty and difficult home circumstances, however, that many dimensions of exclusion precede the child's failure at school (Colley and Hodkinson 2001). To suggest medical solutions for such problems is to tackle the symptom and not the cause, and the connections between New Labour's tendency to select for reconditioning the individuals who are deemed to be deviant to its economic reliance on the furtherance of the pharmaceutical sector (the United Kingdom's one industrial arm that actually contributes new research and development) are to be watched with concern. Rather than evaluate the social uptake of this medicalization of social problems, a vital geography perspective might argue that the geographical inequalities noted earlier for Britain suggest social and environmental causes that raise questions about poverty and whether it is acceptable for life chances to be so heavily determined by class and postal code. At the global level, we are already seeing the consequences of the medicalization of social problems in the "global sanitary apartheid" described by Nguyen and Peschard $(2003,464)$. To respond to these variously scaled geographical problematizations of "life itself" (that is, life understood in its biological and social interconnectedness), we now want to consider some of the ways we might relate vital geographies to geographical justice. In place of static accounts of the geographical determinants of the limits and capacities of human life (e.g., Sachs 2005), we look instead at the interconnectedness of human lives along six dimensions: culpability, fairness, the ethics of care, state failure, human rights, and solidarity.

\section{Toward a Vital Geography}

\section{Putting Privilege and Suffering on the Same Map}

Sontag $(2003,102-03)$ encourages us to reflect "on how our privileges are located on the same map as their suffering" (emphasis added). To do so raises the question of the culpability of the fortunate. There are clearly ways that people living in rich countries benefit from the conditions that make people elsewhere poor and unhealthy. Unfair terms of trade and the use of tariffs and subsidies to help domestic producers in rich countries mean that producers in poor countries receive less than a living wage for products that rich people buy without second thought. The cost of living for the rich and the standard of living for the poor are kept down in concert with one another (Stiglitz and Charlton 2005). The rich are also culpable in the vital fate of the poor through their pursuit of debt repayment, which leaves poor states with even less capacity to deal with the health consequences of poverty (Schoepf, Schoepf, and Millen 2000) and through insisting on rent for intellectual property rights that prevent people in poor countries making or buying the medicines they need (' $t$ Hoen 2002). These structural inequalities persist despite the burden of ill health in poor countries, basically, because more money can be made from treating the sicknesses of rich people. Between 1975 and 1997 only about 1 percent of newly approved drugs were distinctly for tropical diseases (Trouiller and Olliaro 1999). On the basis of the justice arguments we made earlier, because people in rich countries benefit from these asymmetries, they owe people in poor countries redress at the very least, and that means paying heed to inequalities of longevity and how some of these symptoms of an exploitative economic system might be alleviated. The first work of vital geographies, then, is to document inequalities and explain why they arise.

\section{A Fair World}

Alongside our culpability as beneficiaries of "structural violence" (Farmer 2004), we might reflect more explicitly on the "fairness" of geographical luck and what that might imply for how we acknowledge obligations. Although it is not the way Rawls developed his justice-as-fairness argument, we think there is merit in considering the moral claims of a global community. Baker (1987) argues that gross inequality depraves interpersonal relations, allowing rich people to make demands of poor people that they would themselves find degrading. It is clear, for example, that international networks of child adoption rest, in large part, on exploiting the poverty of some families, inducing them to surrender for adoption children who they cannot nurture themselves (Hollingsworth 2003). Singer (1999) proposes that fairness suggests we can defend little of our gratuitous spending while other people must go without even basic needs. If we made such charitable gifts, 
we would be securing a moral good "without sacrificing anything of comparable moral importance" (Singer 1972, 231). This moral imperative, for Singer, is independent of distance or familiarity, as long as one has a reasonable idea of what is needed in distant places. Vital geographies, by documenting need, by focusing on "the impediments to survival" (Heynen 2006, 920), can cultivate the empathy that leads people to accept these sorts of obligations.

\section{Caring for Others}

Health care is a form of repair, and caring stems from an impulse to make good (Spelman 2002). In this regard, empirical work in vital geography might cultivate an ethic of care by nurturing this impulse (D. M. Smith 2000, ch. 5; Popke 2006). Gilligan (1977) argues that alongside the morality of justice, there is a morality based on care. Such moral claims come from a sense of responsibility embedded in particular relationships. They are less abstract than the claims of justice. Tronto (1987) elaborated these insights in suggestive ways by proposing that the status of care is low because it does not derive its claims from universal principles of justice but instead from sentiments arising from affective ties. In this respect, whereas justice is claimed by the dominant social group, care is left as the activity of the subordinate group, be it female or, she speculates, black. Tronto $(1987,658)$ argues that care, as a contextual morality, needs to specify "ways in which individuals progress morally to exhibit concern for others." At the very least, care requires familiarity and thus empathy. Knowing about and imagining the lives of others helps us feel a common humanity (Kirmayer 2003). Such a feeling might be partly what is at work within the sorts of new medical communities Novas and Rose (2000) describe, but it should also be at work within our analyses of the geographical inequalities of life chances such communities take as their raison d'être. Certainly, notions of social caring need to be considered alongside notions of medical or therapeutic care. Gilligan (1983, 44) herself proposed that such an extension of a morality of care depends on "the capacity to assume responsibility for care."

Here again, vital geographies might draw on the notion of geographical luck to advance both imperatives of empathy and capacity. People can cultivate a feeling of having a duty of care toward others by understanding how they do, indeed, already have many relations with distant strangers in commodity chains, through asymmetric travel and migration laws, and through inter- country debt and trade relations that sustain our lives as they curtail theirs, rather than leaving mutual action to the realm of shared biosocial affinities. This seems particularly important, given that, in the area of public health, the cost of effective interventions is relatively modest and thus, in this respect at least, the geographical luck of longevity does indeed invite a duty of care that is eminently dischargeable. The United Nations Global Fund to Fight AIDS, Tuberculosis and Malaria, for example, began work in 2003 and in its first three years it had disbursed grants of $\$ 3.24$ billion (Global Fund 2007). By December 2006, it had 770,000 people on antiretroviral treatment for HIV and 2 million people on directly observed treatment, short course (DOTS) for curing tuberculosis. Some 18 million insecticide-treated bed nets had been distributed to protect families from malaria. Some of these interventions are very cheap. The DOTS cure for tuberculosis costs only $\$ 10$ per person and a treated mosquito net is only $\$ 4$. How do we create rights for such things? Before answering this question, we consider briefly the geography of state capacities (and incapacities) for regulating life because, as often as not, it is such geographies that stand in the way of realizing medical disbursements.

\section{Compromised Sovereignty}

The fourth dimension of geographical luck that we wish to consider is the question of state failure and the obligations that might follow. A range of justifications has been offered for "humanitarian interventions," of various kinds. M. J. Smith $(1998,76)$ follows many, including recent UN policy, when he argues that "a state that is oppressive and violates the autonomy and integrity of its subjects forfeits its moral claim to full sovereignty." We are here in the terrain sketched out by Rawls (1993) in his law of peoples. There is a worrying slippage possible, from pleas for intervention to avert genocide, to interventions in support of more general political freedoms. We do not share the enthusiasm of Boot (2003), Cooper (2003), and Kurtz (2003) for the latter, struck as we are by the danger of new intensified international inequalities being created under the cover of building democracy (Hindess 2001; Rhodes 2003; Rieff 2005) and by the lack of guarantees that the political rights promoted actually result in rights to health.

Nevertheless, it is possible to imagine circumstances in which a people are so badly ruled that health care is denied them by their government. In such a situation, a foreign coalition of the willing might well feel justified in offering to provide and distribute the 
prophylaxis themselves. This at least is the justification for doctors crossing borders, Médicins Sans Frontières (MSF). Whereas the Red Cross and Red Crescent operate only with the consent of states, MSF was willing to act for people lacking a government concerned enough to accept assistance for them (Kouchner 1991). In some respects, though, and against the example of armed humanitarian interference in Kosovo, Afghanistan, and Iraq, MSF has become more and not less wary of crossing borders without permission (Redfield 2006). More's the pity: There is a return flow from medical interventionism to state building. As the Global Fund (2007) argues, developing medical services within poor countries not only trains individuals but advances civil society and state capacities (Walton, Farmer, and Lambert 2004). To return to our earlier argument, there is a sense in Rose that the pastoral state is no more. What we are suggesting here is that the pastoral state has always been a partial state. Some human rights to good health can be acknowledged at the level of the system of states, and when care crosses borders it might even contribute to developing pastoral practices and expectations of care within states.

\section{Global Human Rights}

This discussion of the ethics of crossing borders raises further questions about ethnocentrism, Western norms, and the question of an acceptable basis for interference in the public health of other states. Reclus $(1908,528)$ wrote that " $t$ the conquest of bread ... does not consist only in eating, but in eating bread that is one's human right." ${ }^{2}$ In other words, mere abundance, the availability of food, would not end hunger. Similarly, health is not guaranteed by medicine or technology but only where people have a right to lives not unnecessarily damaged by toxins, exhaustion, and dangerous workplaces, and where, when they do fall ill, they have fair access to health care and to the medicines that should be considered the collective property of humankind.

In his Nobel Prize speech on behalf of MSF, Orbinski proposed that "[b]ringing medical aid to people in distress is an attempt to defend them against what is aggressive to them as human beings" and, furthermore, that this action aims to "enable individuals to regain their rights and dignity as human beings" (MSF 1999). The dominant principles of human rights are set out in the Universal Declaration of Human Rights, based on removing obstacles to human autonomy and dignity. Article 25 mentions specifically a standard of living adequate for "health and well-being," which includes "medical care." In the name of this principle people raise justice claims in consequence of the geographical luck of longevity. Indeed, these issues are at the heart of Sen's (1999) presentation of development as freedom. Social and economic rights, he suggests, are essential to the dignity and autonomy we call freedom, or as we put it earlier, the capacity of exercising our free will, of truly living. To say, however, that from a sense of justice, fairness, or caring, we conceive an obligation to address the suffering of others is to assert that we know how to do so and thus raises three sets of concerns about acting on such an international obligation: effectiveness, justification, and commitment.

Tronto (1993) writes of care as a practical rationality that rests on four ethical elements: the attentiveness of noticing need in others, the responsibility of accepting an obligation to help, the competence of knowing what is needed, and the responsiveness of finding out how effectively care is received. Some argue that perceptions of incompetence are often merely the projection onto others of our own local norms: They must need what we think we need. The problem of effectiveness (that is, of competence and responsiveness) is well illustrated by medical humanitarianism. Medical assistance to refugees, for example, can become a way simply of maintaining them as bare life and refiguring international concern as about nothing more. Refugee life is politically disqualified in Agamben's (1998) terms. For example, Turner (2005) describes a camp for refugees from Burundi living in Tanzania. There, any such politics as exist in the camp can take place only around the basic provisioning for everyday life because the Tanzanian state does not want to be drawn into conflict with its neighbor. This in turn raises the question of how to address the root causes of suffering, a question addressed within MSF for one through the politics of bearing witness; making the plight of the suffering people known outside their country, to act as international advocates calling attention to the betrayal of global human rights (Redfield 2006).

Some do not see the justification for this sort of global human rights culture. Butt (2002a), for example, has suggested that the very injustices that are at the heart of structural violence likewise deform global morality, while the notions of equality articulated in such academic and advocacy writings are of a piece with the very forces of liberalism that incorporate the poor into unequal international relations. In West Papua, suggests Butt (2002b, 32), many reject MSF initiatives, which they see as "replicat[ing] existing forms of class and ethnic bias between indigenous Papuans and Indonesians." 
This is largely an ad hominem critique, however, although at another level, it is a variant on the arguments against cosmopolitanism and in favor of difference and local autonomy. Cheah (1997) has explained very lucidly how a sort of culturalist cosmopolitanism elides material determinations of disadvantage and sidelines one of the few movements addressing neocolonialism, nationalism. Yet, medicine is not only a social knowledge, it is also material and it can be effective (Das 2006). Disease feeds stigma and exclusion (Briggs 2005) in ways that good health might address. There are, in any case, few truly local medical discourses anymore and all are a product of a historical geography of interconnectedness so that we might view difference in this field as "temporary localisation" (Apadurai 1988). If we conceive that people have a right to healthy life closer to the global "golden mean," as Aristotle put it, then we are justified in caring, so long as we pay attention to the ethical principles of care. Competence and responsiveness are part of that justification.

Western biomedical products are already part of medical systems in many parts of the world and they are not always used well, either in rich or in poor places. If we believe that certain medicines will work to restore health to people, then we can explain this belief to them and give them the opportunity to receive the medicines. Commodified medicine may well turn iatrogenic but that is less likely with pro bono clinics as long as their science is put at the service of social justice. Indeed, MSF has set up its own research facility, Epicentre, precisely to do so. Likewise, the Global Fund is training medical staff in the places in which it works. Local people are recruited to preventive programs from which they have themselves already benefited. There are dangers that commercial medicine can distort these relations in pursuit of profit but both MSF and the Global Fund are campaigning very actively around questions of pharmaceutical pricing and patents. The queues outside free clinics suggest that many poor people will seek the benefit of this medicine. In many cases, they also come to articulate a sense that all people should get the medical care they need. Medical charity can build local institutions and local civil society.

Perhaps a more pertinent critique is that of commitment: that people can become dependent on medicines that are then retracted when the charity drip they are on runs dry, or the organization is compelled for reasons of its own security (and on the basis of the value it attaches to the lives of its "own" people) to pull out. The funds that nongovernmental organizations (NGOs) compete for are often "sporadic and short term," despite "the universal recognition that $\mathrm{NGOs}$ and their activities are required for many years" (Frangonikolopoulos 2005, 58). Such interruptions can be very dangerous, for example, to the health of people placed on antiretroviral therapies to control their HIV disease (Li et al. 2005).

The criticisms of humanitarianism are sometimes overplayed but there is plenty of evidence that the more pertinent of the critics are being listened to and that there is indeed more practical criticism now being expressed within rather than outside these organizations. Vital geographies should study the practice of care within humanitarian agencies to develop some answers to the common criticisms of global rights-based culture as insensitive and intrusive. At the same time, this should square off against the different sorts of arguments put forward by Rorty: that solidarity (equal care with respect to those we are unequally connected to) is untenable and one is best served by working on the contingent factors that dictate why we care more for some than for others: "that we try to extend our sense of 'we' to people whom we have previously thought of as 'they"' (Rorty 1989, 192). We might agree with him in this sense at least that human solidarity is "made rather than found" (195) to the extent that this places the burden of action proportionately on the bearers of its agency.

Once it is recognized that there is an international right to health, there is an obligation to think pragmatically about how it may best be conceptualized and secured. We are persuaded by Nussbaum's (2006) account of an "overlapping consensus" (300) around a series of human capacities that must be sustained (to a minimal level) as basic to the good life. Although these rights are due to all and the responsibilities fall on all capable of discharging them, we accept Nussbaum's argument that these rights are best secured, and the duty best discharged, by supporting institutions that can address the collective action problem at the heart of health care. We have described how existing NGO practices contribute to building institutional capacity within poorer countries. Supporting the work of charities is one part of this process, but more effective by far is the proper funding of this duty through general taxation in richer countries. Here, too, it is clear that states have an important role to play.

\section{Global Justice Movements}

We have argued that the harms that produce ill health and shorter lives in some places are in turn shaped by the interrelations of states and capital. Yet, 
the proposals for change that we have considered so far address states and capital only insofar as they impact directly on health outcomes. Thus we have remarked on how medical charities and NGOs might develop state capacities in the ways they deliver care. We have commented on the regulatory regimes and property rights associated with medicines and medical technologies. In other words, we have examined the political economy of medicine and of health care even though we recognize that the distribution of wealth and poverty is itself directly shaped by a broader political economy: unfair terms of trade, egregious debt arrangements, and the use of military force, the threat of force, or support for military juntas to enforce the privatization of the commons in poorer or weaker countries. There are two reasons for taking this direction. First, we want to focus on human vitality as the measure of injustice. It is in large part because the broader political economy has unfair consequences for the life chances of people in distant places that it stands condemned. We want to place the emphasis on life's capacities, and thus would condemn exploitation because it harms life, rather than because in some zero-sum calculation some get more goods and others get less. Issues of global governance are thus prioritized in a distinctively vital way (Soskolne 2007). Second, we want to identify what can be done in a palliative sense to redress some of the consequences of unfair economic situations. To the extent that such harms can be attended to, they should be, because to do so would be a worthy achievement in its own right. To postpone what can be done to make lives better now, awaiting a more general rearrangement of the global political economy, is to discount present suffering against future benefit. Life is linear, and harm now is not easily compensated by later ease.

There are, however, many movements that engage directly with the broader political economy and do so in the name of life. Hawken $(2007,2)$ estimates that there are between 1 and 2 million organizations campaigning around the interrelated issues of environmental and social justice. He summarizes their common ground quite simply: "[l]ife is the most fundamental human right, and all of the movements within the movement are dedicated to creating the conditions for life, conditions that include livelihood, food, security, peace, a stable environment, and freedom from external tyranny" (Hawken 2007, 68). Vital geographies should study this movement and, as with the wisdom developed within NGOs, should seek to learn from its experiences. This overlapping set of solidarities is enriching our understanding of how rights-based arguments can be used to defend life.
From the "diversity of autonomy" (Hawken 2007, 18) comes a series of ideas rather than the focus of a single ideology, yet there are common features already plain. The movement incorporates a deep respect for indigenous peoples as custodians of the "greatest remaining sanctuaries of life on earth" (Hawken 2007, 7) and for their long-term planetary rather than short-term economic perspective on the vitality of civilization. The grounds of the solidarities within this movement need to be studied explicitly. Charging crimes against humanity has proven to be one effective way to make transnational solidarities effective (G. Robertson 2006) and this approach could be extended, for example, into the world of work around issues of slavery and child labor (Kearns 2008). This perspective prioritizes the most heinous of injuries.

Canguilhem identified a "vitalist imperative" as an expression of "the mind's capacity, as living consciousness of life, to identify with the living as like with like" (quoted in Philo 2007, 88). In a brilliant survey, Philo notes that Canguilhem's vitalism yet leaves room for humanism, because "for all his vitalist leanings, he also gives special credence to the suffering human being" (Philo 2007, 89). Canguilhem reaches these conclusions through an examination of the genealogy of the notions of "normal" and "pathological," but our argument here is that we might likewise ground such an orientation in an examination of what exactly it is that has enabled environmental and social justice movements to organize global solidarities around issues pertaining to life. Some such wisdom is at the heart of this global movement of movements that extends care to other persons, and to other living things, and it is from that perspective that it has developed a series of critical observations on "globalization," seen as an assault on the autonomy, integrity, and survival of indigenous societies in the cause of short-term gain for distant investors.

\section{Conclusion: Health, Geography, and Luck}

At the beginning of this article we presented a twofold definition of life, as that determined by both its limits and its capacities. The sociology of possibility that we surveyed has tended to focus attention on the modification and enhancement of life's capacities, at the expense of the also much-needed enquiry into life's limits. By drawing attention to the geography that underpins vital knowledges and practices, and by elucidating some of the basic power relations that underlie 
such practices (power relations shaped most fundamentally, we feel, by the twin poles of states and capital), we have sought to redress the balance somewhat. Life as a bare quantitative good that can be measured in years and plotted on maps presents no less intriguing ethical, moral, and sociological questions than do processes by which vital capacities are technologically and culturally altered. In fact, as we hope to have shown, the most interesting and complex questions are those that investigate the mutually constitutive relationship between advancement of our capacity to shape life at one end of the spectrum and to neglect it at the other. We have argued for the need not only for a "geographical" vision of life to counterbalance the "molecular" vision promoted by some scholars but also for a mode of intellectual enquiry that encompasses the two. The rearticulation of some lives is bound up in a longer running dearticulation of others. So much of consequence for longevity and health flows from the accident of place of birth, and from the constrained choice of residence, that we must recognize and reflect on the significance of what we term geographical luck.

The effects of geographical luck can be seen perhaps most starkly by focusing at the international level. Acknowledging that the international is but one relevant scale needing consideration, we have also sought to delineate what such an approach might look like. In particular, we have tried to show that a vital geographical approach needs to examine the interconnectedness of human lives between places and across scales of action. We set out six dimensions of interconnectedness that raise fundamental questions of duty and care. This approach might disappoint those who argue that nothing short of the abolition of the global capitalist system can address the fundamental causes of social problems. Such arguments find themselves paralyzed by the impossibility of bringing this about within an acceptable time scale and with acceptable social costs. Instead, an approach that sets the explanation of inequality, the documentation of need, and the fostering of an ethic of care alongside an awareness of the structural difficulties in enacting such care and the duty to discharge it effectively, should be supportive of attempts to recognize and mitigate contextual constraints with the greatest dispatch possible.

A vital geographical analysis thus considers technological developments and emergent possibilities for life as elements on a wider plane of moral and political economy. The technological mediation of life itself has a long history and is not limited simply to developments in biomedicine, and the pertinent aspects of that his- tory should be brought to the fore when studying it. At the same time, new technological capacities refashion long-standing questions of how and why some individuals are morally obliged to help others in need. Health and geography are thus not just two words of a subdiscipline engaged in asking these very questions; they are coordinates for a necessary and just ethic of care.

\section{Acknowledgments}

We would like to acknowledge the support of the Economic and Social Research Council (Grant No. RG48163), which funded the seminar series for which this article was produced. We would also like to thank the seminar participants for their advice and comments. Gerry Kearns would like to acknowledge sabbatical support from the University of Cambridge and research support from Jesus College, Cambridge, as well as the facilities offered by the Institute of Advanced Studies at the University of MinnesotaMinneapolis where a Visiting Fellowship provided a stimulating environment for developing some of these ideas. Simon Reid-Henry would like to thank members of the Health, Place and Society research group at Queen Mary, University of London, for their support of the vital geographies project and their advice on some of the arguments herein and the Department of Geography at the University of Macquarie, Sydney, for hosting him as Visiting Fellow during part of the writing. We are particularly grateful to the following for the improvements they suggested: Richard Ashcroft, Bruce Braun, Michael Brown, Vinny del Casino, John Cornwell, Susan Craddock, Paul Draus, Rory Gallagher, Matt Gandy, Jon Harkness, Clare Herrick, Alan Ingram, Steve Legg, Jay Levy, David Nally, Vinh-Kim Nguyen, Jim Oeppen, Brian Salter, Richard Smith, Katerini Storeng, Karen Till, Andy Tucker, and Sridhar Venkatapuram. Thanks also to the referees and to Audrey Kobayashi for constructive suggestions.

\section{Notes}

1. We are grateful to one of the referees for pointing out to us this implication of Western universality.

2. "La conquête du Pain... ne s'agit pas simplement de manger, mais de manger le pain dû a son droît d'homme."

\section{References}

Agamben, G. 1998. Homo sacer: Sovereign power and bare life. Stanford, CA: Stanford University Press. 
Allotey, P., D. Reidpath, A. Kouame, and R. Cummins. 2003. The DALY, context and the determinants of the severity of disease: An exploratory comparison of paraplegia in Australia and Cameroon. Social Science and Medicine 57:949-58.

Amnesty International, CARE International UK, CAFOD, Christian Aid, Médecins du Monde UK, Oxfam, Save The Children UK, and Trócaire. 2008. The Gaza Strip: A humanitarian implosion. London: Amnesty International. http://www.careinternational.org.uk/download.php?id= 739 (last accessed 25 March 2008).

Anderson, W. 2004. Natural history of infectious disease: Ecological vision in twentieth century biomedical science. Osiris 19:39-61.

Apadurai, A. 1988. Putting hierarchy in its place. Cultural Anthropology 3:36-49.

Arnesen, T., and L. Kapiriri. 2004. Can the value choices in DALYs influence global priority-setting? Health Policy 70 (2): 137-49.

Arnold, D. 1994. Colonizing the body: State medicine and epidemic disease in nineteenth century India. Berkeley: University of California Press.

Baker, J. 1987. Arguing for equality. London: Verso.

Barnett, T., and A. Whiteside. 2002. AIDS in the twentyfirst century: Disease and globalization. Basingstoke, UK: Palgrave Macmillan.

Bell, M., T. Brown, and L. Faire. 2006. Germs, genes and postcolonial geographies: Reading the return of tuberculosis to Leicester, UK, 2001. Cultural Geographies 13:57799.

Benatar, S. 2003. Bioethics: Power and injustice: IAB Presidential Address. Bioethics 17:387-98.

- 2005. Moral imagination: The missing component in global health. PLoS Med 2:e400.

Benatar, S., A. S. Daar, and P. A. Singer. 2003. Global health ethics: The rationale for mutual caring. International Affairs 79:107-38.

Berlin, I. 1958. Two concepts of liberty. Oxford, UK: Clarendon.

Biehl, J. 2005. Vita: Life in a zone of social abandonment. Berkeley: University of California Press.

Bloche, M. G., and J. H. Marks. 2005. Doctors and interrogators at Guantanamo Bay. New England Journal of Medicine 353:6-8.

Bond, P. 1999. Basic infrastructure for socio-economic development, environmental protection and geographical desegregation: South Africa's unmet challenge. Geoforum 30:43-59.

Boot, M. 2003. Neither new nor nefarious: The liberal empire strikes back. Current History 102:361-66.

Braun, B. 2007. Biopolitics and the molecularization of life. Cultural Geographies 14:6-28.

Briggs, C. L. 2005. Communicability, racial discourse, and disease. Annual Review of Anthropology 34:269-91.

Brody, S. N. 1974. Disease of the soul: Leprosy in medieval literature. Ithaca, NY: Cornell University Press.

Brown, N., and A. Webster. 2004. New medical technologies and society: Reordering life. Cambridge, UK: Polity Press.

Brown, T. 2000. AIDS, risk and the governance of social space. Social Science and Medicine 50:1273-84.

Burrows, R., N. Pleace, and D. Quilgars, eds. 1997. Homelessness and social policy. London and New York: Routledge.
Butt, L. 2002a. Reply to Alec Irwin, Joyce Millen, Jim Kim, John Gershman, Brooke G. Schoepf, and Paul Farmer. Medical Anthropology 21:31-33.

2002b. The suffering stranger: Medical anthropology and international morality. Medical Anthropology 21:124.

Canguilhem, G. [1966] 1991. The normal and the pathological. New York: Zone Books.

Cheah, P. 1997. Given culture: Rethinking cosmopolitical freedom in transnationalism. Boundary 2 (24): 157-97.

Clarke, A. E., L. Mamo, J. R. Fishman, J. K. Shim, and J. R. Fosket. 2003. Biomedicalization: Technoscientific transformations of health, illness and U.S. biomedicine. American Sociological Review 68:161-94.

Cohen, J. 2000. The Global Burden of Disease study: A useful projection of future global health? Journal of Public Health Medicine 22:518-24.

Cohen, L. 2005. Operability, bioavailability, and exception. In Global assemblages: Technology, politics, and ethics as anthropological problems, ed. A. Ong and S. J. Collier, 79-90. Malden, MA: Blackwell.

Colley, H., and P. Hodkinson. 2001. Problems with "Bridging the gap": The reversal of structure and agency in addressing social exclusion. Critical Social Policy 21:335-59.

Collier, S., and A. Ong, eds. 2005. Global assemblages: Technology, politics, and ethics as anthropological problems. Malden, MA: Blackwell.

Cooper, R. 2003. The breaking of nations: Order and chaos in the twenty-first century. London: Atlantic Books.

Corbridge, S. 1993. Marxisms, modernities, and moralities: Development praxis and the claims of distant strangers. Environment and Planning D: Society and Space 11:44972.

Craddock, S. 2000. City of plagues: Disease, poverty, and deviance in San Francisco. Minneapolis: University of Minnesota Press.

Daniels, N. 1985. Just health care. Cambridge, UK: Cambridge University Press.

Das, V. 2006. Poverty, marginality, and illness. American Ethnologist 33:27-32.

Davis, M. 2005. The monster at our door: The global threat of Avian flu. New York: The New Press.

Del Casino, V. 2004. (Re)placing health and health care: Mapping the competing discourses and practices of "traditional" Thai medicine. Health and Place 10:59-73.

Diprose, R. 1995. The body biomedical ethics forgets. In Troubled bodies: Critical perspectives on postmodernism, medical ethics, and the body, ed. P. Komesaroff, 202-21. Durham, NC: Duke University Press.

Draus, P. 2004. Consumed in the city: Observing tuberculosis at century's end. Philadelphia: Temple University Press.

Epstein, S. 2003. Sexualizing governance and medicalizing identities: The emergence of "state-centred" LGBT health politics in the United States. Sexualities 6:13171.

. 2004. Bodily differences and collective identities: The politics of gender and race in biomedical research in the United States. Body and Society 10:183-203.

Farmer, P. 2004. An anthropology of structural violence. Current Anthropology 45:305-17.

Fischer, M. J. 2003. Emergent forms of life and the anthropological voice. Durham, NC: Duke University Press. 
Fleuret, S., and S. Atkinson. 2007. Wellbeing, health and geography: A critical review and research agenda. New Zealand Geographer 63:106-18.

Foot, R. 2006. Torture: The struggle over a peremptory norm in a counter-terrorist era. International Relations 20:13151.

Frangonikolopoulos, C. A. 2005. Non-governmental organisations and humanitarian action: The need for a viable change of praxis and ethos. Global Society 19:49-72.

Franklin, S. 2000. Life itself: Global nature and the genetic imaginary. In Global nature, global culture, ed. S. Franklin, C. Lury, and J. Stacey, 188-227. London: Sage.

Friedman, S. R., R. Curtis, A. Neaigus, B. Jose, and D. C. Des Jarlais. 1999. Social networks, drug injectors' lives, and HIVIAIDS. New York: Kluwer Academic.

Gallup, J. L., J. D. Sachs, and A. D. Mellinger. 1999. Geography and economic development. International Regional Science Review 22:179-232.

Gamble, V. N. 1997. Under the shadow of Tuskegee: African Americans and health care. American Journal of Public Health 85:1773-78.

Gilligan, C. 1977. In a different voice: Women's conceptions of self and morality. Harvard Educational Review 47:481517.

. 1983. Do the social sciences have an adequate theory of moral development? In Social science as moral inquiry, ed. N. Haan, R. N. Bellah, P. Rabinow, and W. Sullivan, 33-51. New York: Columbia University Press.

Global Fund. 2007. Partners in impact: Results report. Geneva: Global Fund.

Greely, H. T. 2000. Iceland's plan for genomics research: Facts and implications. Jurimetrics 40:153-91.

Greenhalgh, S. 2003. Planned births, unplanned persons: "Population" in the making of Chinese modernity. American Ethnologist 30:196-215.

Greenhough, B. 2006. Imagining an island laboratory: Representing the field in geography and science studies. Transactions of the Institute of British Geographers 31:224-37.

Gregory, D., and A. Pred, eds. 2006. Violent geographies: Fear, terror and political violence. London and New York: Routledge.

Hacking, I. 1982. Biopower and the avalanche of printed numbers. Humanities in Society 5:279-95.

. 1998. Mad travelers: Reflections on the reality of transient mental illnesses. Charlottesville, VA: University of Virginia Press.

- 2006. Kinds of people: Moving targets. www.britac. ac.uk/pubs/src/britacad06/index.html (last accessed 3 July 2007).

Hall, E. 2004. Spaces and networks of genetic knowledge making: The "geneticisation" of heart disease. Health and Place 10:311-18.

Hardy, A. 1993. The epidemic streets: Infectious disease and the rise of preventive medicine, 1856-1900. Oxford, UK: Oxford University Press.

Harkness, J. 1996. Research behind bars: A history of nontherapeutic research on American prisoners. PhD dissertation, University of Wisconsin, Madison, WI.

Hawken, P. 2007. Blessed unrest: How the largest movement in the world came into being and why no one saw it coming. New York: Viking.

Heynen, N. 2006. "But it's alright, Ma, it's life, and life only": Radicalism as survival. Antipode 38:916-29.
Hindess, B. 2001. Not at home in the empire. Social Identities 7:363-77.

Hollingsworth, L. D. 2003. International adoption among families in the United States: Considerations of social justice. Social Work 48:209-17.

Ingram, A. 2007. HIV/AIDS, security, and the geopolitics of U.S.-Nigerian relations. Review of International Political Economy 14:510-34.

Jones, E. L. 1981. The European miracle: Environments, economies, and geopolitics in the history of Europe and Asia. Cambridge, UK: Cambridge University Press.

Jones, J. H. 1981. Bad blood: The Tuskegee syphilis experiment. New York: Free Press.

Kant, I. [1790] 1911. The critique of judgement. Trans. J. C. Meredith. Oxford, UK: Clarendon.

Kawachi, I., B. P. Kennedy, K. Lochner, and D. ProtrowStith. 1997. Social capital, income inequality, and mortality. American Journal of Public Health 87:149198.

Kearns, G. 2006. The social shell. Historical Geography 34:4970.

. 2008. Progressive geopolitics. Geography Compass 2 (5): 1599-620.

King, N. 2002. Security, disease, commerce: Ideologies of postcolonial global health. Social Studies of Science 32:763-89.

Kinsella, K., and Y. J. Gist. 1998. Gender and aging: Mortality and health. U.S. Census Bureau International Brief 98-2. Washington, DC: U.S. Census Bureau.

Kirmayer, L. J. 2003. Failures of imagination: The refugee's narrative in psychiatry. Anthropology and Medicine 10:167-85.

Klein, N. 2007. Shock doctrine: The rise of disaster capitalism. New York: Metropolitan Books.

Klinenberg, E. 2002. Heat wave: A social autopsy of disaster in Chicago. Chicago: University of Chicago Press.

Kouchner, B. 1991. Le malheur des autres [The suffering of others]. Paris: Editions Odile Jacob.

Kurtz, S. 2003. Democratic imperialism: A blueprint. Policy Review 118:3-20.

Lakoff, A. 2005. Pharmaceutical reason: Knowledge and value in global psychiatry. Cambridge, UK: Cambridge University Press.

Li, X., J. B. Margolick, C. S. Conover, S. Badri, S. A. Riddler, M. D. Witt, and L. Jacobson. 2005. Interruption and discontinuation of highly active antiretroviral therapy in the multicenter AIDS cohort study. JAIDS Journal of Acquired Immune Deficiency Syndromes 38:32028.

Lock, M. 2002. Twice dead: Organ transplants and the reinvention of death. Berkeley: University of California Press.

MacKlan, S. C. 2008. What the papers say: Reading therapeutic landscapes of women's health and empowerment in Uganda. Health and Place 14:106-15.

Marmot, M. 2005. Social determinants of health inequalities. Lancet 365:1099-104.

Martin, E. 1987. The woman in the body: A cultural analysis of reproduction. Boston: Beacon Press.

. 1992. The end of the body? American Ethnologist 19:121-40.

Mbali, M. n.d. The Treatment Action Campaign and the history of rights-based patient-driven activism in South Africa. University of Kwazulu-Natal Centre for Civil 
Society, Research Report No. 29. http://www.ukzn.ac. za/ccs/files/RReport_29.pdf (last accessed 4 July 2007).

Médecins Sans Frontières. (MSF). 1999. The 1999 Nobel lecture. http://nobelprize.org/peace/laureates/1999/msflecture.html (last accessed 11 April 2007).

Mitford, J. 1973. Experiments behind bars: Doctors, drug companies, and prisoners. Atlantic Monthly 23 January:64-73.

Moynihan, R., I. Heath, and D. Henry. 2002. Selling sickness: The pharmaceutical industry and disease mongering. British Medical Journal 324:886-91.

Murray, C. J., and A. D. Lopez, ed. 1996. The global burden of disease. Geneva: World Health Organization.

National Institutes of Health. 1993. IRB (Institutional Review Boards). In The IRB guidebook_1993. Washington, DC: Office for Protection from Research Risks, National Institutes of Health. http://www.nih.gov/ grants/oprr/irb/irb_chapter6.htm\#gt (last accessed 4 July 2007).

Nguyen, V.-K. 2005. Antiretroviral globalism, biopolitics and therapeutic citizenship. In Global assemblages: Technology, politics, and ethics as anthropological problems, ed. A. Ong and S. J. Collier, 124-44. Malden, MA: Blackwell.

Nguyen, V.-K., and K. Peschard. 2003. Anthropology, inequality, and disease: A review. Annual Review of Anthropology 32:447-74.

Noh, S., M. Beiser, V. Kaspar, F. Hou, and J. Rummens. 1999. Perceived racial discrimination, discrimination, and coping: A study of South East Asian refugees in Canada. Journal of Health and Social Behaviour 40:193-207.

North, C. S., K. M. Eyrich, D. E. Pollio, and E. L. Spitznagel. 2004. Are rates of psychiatric disorders in the homeless population changing? American Journal of Public Health 94:103-08.

Novas, C., and N. Rose. 2000. Genetic risk and the birth of the somatic individual. Economy and Society 29:485-513.

Nussbaum, M. 2006. Frontiers of justice: Disability, nationality, species membership. Cambridge, MA: Harvard University Press.

Office for National Statistics (ONS). 2006a. Life expectancy at birth for all persons by ward in England and Wales, 1999-2003 (experimental statistics). http://www. statistics.gov.uk/downloads/theme_health/Ward_LE_ Persons.xls (last accessed 19 July 2006).

2006b. Trends in life expectancy by social class 1972-2001. http://www.statistics.gov.uk/downloads/theme population/Life_Expect_Social_class_1972_01/Life_Expect _Social_Class_1972-2001.pdf (last accessed 20 July 2006).

Pálsson, G. 2007. Anthropology and the new genetics. Cambridge, UK: Cambridge University Press.

Patton, C. 2002. Globalizing AIDS. Minneapolis: University of Minnesota Press.

Patton, P. 1989. Taylor and Foucault on power and freedom. Political Studies 37:260-76.

Petryna, A., and A. Kleinman. 2006. The pharmaceutical nexus. In Global pharmaceuticals: Ethics, markets, practices, ed. A. Petryna, A. Lakoff, and A. Kleinman, 1-32. Durham, NC: Duke University Press.

Petryna, A., A. Lakoff, and A. Kleinman. 2006. Global pharmaceuticals: Ethics, markets, practices. Durham, NC: Duke University Press.
Phillips, E. D. 1987. Aspects of Greek medicine. London: Croom Helm

Philo, C. 2004. A geographical history of institutional provision for the insane from medieval times to the 1860s in England and Wales: The space reserved for insanity. Lampeter, UK: Edwin Mellen Press.

. 2007. A vitally human medical geography? Introducing Georges Canguilhem to geographers. New Zealand Geographer 63:82-96.

Popke, J. 2006. Geography and ethics: Everyday mediations through care and consumption. Progress in Human Geography 30:505-12.

Porter, R. 1997. The greatest benefit to mankind: A medical history of humanity from antiquity to the present. London: Fontana.

Quinlan, S. 1996. Colonial bodies, hygiene and abolitionist politics in eighteenth-century France. History Workshop Journal 42:107-25.

Rabinow, P. 1992. Artificiality and enlightenment: From sociobiology to biosociality. In Incorporations, ed. J. Kwinter and P. Crary, 234-53. San Francisco: Zone Books.

1999. French DNA: Trouble in purgatory. Chicago: Chicago University Press.

Rapp, R. 1999. Testing women, testing the fetus: The social impact of amniocentesis in America. London and New York: Routledge.

Rawls, J. 1971. A theory of justice. Cambridge, MA: Belknap Press.

68

Reclus, E. 1908. L'homme et la terre. VI. Histoire contemporaine (suite) [Humanity and the Earth. VI. Modern history (continued)]. Paris: Librairie Universelle.

Redfield, P. 2006. A less modest witness: Collective advocacy and motivated truth in a humanitarian movement. American Ethnologist 33:3-26.

Reid-Henry, S. Forthcoming. The Cuban cure: Reason and resistance in global science. Chicago: Chicago University Press.

Renzaho, A. M. N. 2004. Fat, rich and beautiful: Changing socio-cultural paradigms associated with obesity risk, nutritional status and refugee children from sub-Saharan Africa. Health and Place 10:105-13.

Rhodes, E. 2003. The imperial logic of Bush's liberal agenda. Survival 45:131-54.

Rieff, D. 2005. At the point of a gun: Democratic dreams and armed intervention. New York: Rowman and Littlefield.

Robertson, A. 1998. Critical reflections on the politics of need: Implications for public health. Social Science and Medicine 47:1419-30.

Robertson, G. 2006. Crimes against humanity: The struggle for global justice. 3rd ed. London: Penguin.

Rorty, R. 1989. Contingency, irony, and solidarity. Cambridge, UK: Cambridge University Press.

Rose, N. 2006. The politics of life itself: Biomedicine, power, and subjectivity in the twenty-first century. Princeton, NJ: Princeton University Press.

Sachs, J. 2005. The end of poverty: Economic possibilities for our time. New York: Penguin.

Saracci, R. 1997. The World Health Organisation needs to reconsider its definition of health. British Medical Journal 314:1409-10. 
Scarry, E. 1985. The body in pain: The making and unmaking of the world. New York: Oxford University Press.

Scheper-Hughes, N., and M. Lock. 1987. The mindful body: A prolegomenon to future work in medical anthropology. Medical Anthropology Quarterly 1:6-41.

Schoepf, B. G., C. Schoepf, and J. V. Millen. 2000. Theoretical therapies, remote remedies: SAPs and the political ecology of poverty and health in Africa. In Dying for growth: Global inequality and the health of the poor, ed. J. Y. Kim, J. V. Millen, A. Irwin, and J. Gershman, 91-125. Monroe, ME: Common Courage Press.

Sen, A. 1998. Mortality as an indicator of economic success and failure. Economic Journal 108:1-25.

-1999. Development as freedom. New York: Oxford University Press.

Sennett, R. 1996. Flesh and stone: The body and the city in western civilization. London: Norton.

Singer, P. 1972. Famine, affluence, and morality. Philosophy and Public Affairs 1:229-43.

1999. The Singer solution to world poverty. New York Times Sunday Magazine 5 September:60-63.

Smith, D. M. 2000. Moral geographies: Ethics in a world of difference. Edinburgh, UK: Edinburgh University Press.

Smith, M. J. 1998. Humanitarian intervention: An overview of the ethical issues. Ethics and International Affairs 12:6379.

Social Exclusion Unit (SEU). 1999. Bridging the gap: New opportunities for 16-18 year olds. London: HMSO.

Sontag, S. 2003. Regarding the pain of others. New York: Farrar, Strauss, and Giroux.

Soskolne, C. L., ed., with L. Westra, L. J. Kotzé, B. Mackey, W. E. Rees, and R. Westra. 2007. Sustaining life on earth: Environmental and human health through global governance. Lanham, MD: Rowman and Littlefield.

Spelman, E. V. 2002. Repair: The impulse to restore in a fragile world. Boston: Beacon Press.

Stiglitz, J. E., and A. Charlton. 2005. Fair trade for all: How trade can promote development. Oxford, UK: Oxford University Press.

Subramanian, S. V., and I. Kawachi. 2006. Whose health is affected by income inequality? A multilevel interaction analysis of contemporaneous and lagged effects of state income inequality on individual self-rated health in the United States. Health and Place 12:141-56.

Substance Abuse and Mental Health Services Administration. 2006. Homeless admissions to substance abuse treatment: 2004. The DASIS Report Issue 26. http://www.oas. samhsa.gov/2k6/homeless/homeless.pdf (last accessed 4 July 2007).

Sunder Rajan, K. 2006. Biocapital: The constitution of postgenomic life. Durham, NC: Duke University Press.

Swabe, J. 1999. Animals, disease and human society: Humananimal relations and the rise of veterinary medicine. London and New York: Routledge.

Thacker, E. 2003. Data made flesh: Biotechnology and the discourse of the posthuman. Cultural Critique 53:72-97.

't Hoen, E. 2002. TRIPS, pharmaceutical patents, and access to essential medicines: A long way from Seattle to Doha. Chicago Journal of International Law 3:27-46.
Treichler, P. 1999. How to have theory in an epidemic: Cultural chronicles of AIDS. Durham, NC: Duke University Press.

Tronto, J. C. 1987. Beyond gender difference to a theory of care. Signs 12:644-63.

-1993. Moral boundaries: A political argument for an ethic of care. London and New York: Routledge.

Trouiller, P., and P. Olliaro. 1999. Drug development output from 1975 to 1996: What proportion for tropical diseases? International Journal of Infectious Diseases 3:6163.

Turner, S. 2005. Suspended spaces-Contesting sovereignties in a refugee camp. In Sovereign bodies: Citizens, migrants, and states in the postcolonial world, ed. T. B. Hansen and F. Stepputat, 312-32. Princeton, NJ: Princeton University Press.

United Nations Development Programme (UNDP). 2005. Human development report 2005: International cooperation at a crossroads: Aid, trade and security in an unequal world. http://hdr.undp.org/en/media/HDR05_complete.pdf (last accessed 1 May 2009).

Wainwright, S., C. Williams, M. Michael, B. Farsides, and A. Cribb. 2006. Ethical boundary-work in the embryonic stem cell laboratory. Sociology of Health and Illness 28:732-48.

Waldby, C., and R. Mitchell. 2007. Tissue economies: Blood, organs, and cell lines in late capitalism. Durham, NC: Duke University Press.

Wallace, D., and R. Wallace. 1998. A plague on your houses: How New York was burned down and national public health crumbled. London: Verso.

Walton, D. A., P. E. Farmer, and W. Lambert. 2004. Integrated HIV prevention and care strengthens primary health care: Lessons from rural Haiti. Journal of Public Health Policy 25:137-58.

Watson, D. B., M. J. Murtagh, J. E. Lally, R. G. Thomson, and S. McPhail. 2007. Flexible therapeutic landscapes of labour and the place of pain relief. Health and Place 13:865-76.

Wilkinson, L. 1992. Animals and disease: An introduction to the history of comparative medicine. Cambridge, UK: Cambridge University Press.

Wilkinson, R. G. 1996. Unhealthy societies: The afflictions of inequality. London and New York: Routledge.

Wilson, K. 2003. Therapeutic landscapes and First Nations peoples: An exploration of culture, health and place. Health and Place 9:89-93.

Wohl, D. A. 1999. Clinical trial research in correctional settings. HIV Education Prison Project Newsletter, August-September. http://www.aegis.com/pubs/hepp/ 1999/HEPP1999-0801.html (last accessed 4 July 2007).

Wolfson, M., G. Kaplan, J. Lynch, N. Ross, and E. Backlund. 1999. Relation between income inequality and mortality: Empirical demonstration. British Medical Journal 319:953-55.

World Health Organization. (WHO). 2005. Basic documents. 45th ed. Geneva: World Health Organization.

_. 2007. Disability Adjusted Life Year (DALY). http:// www.who.int/healthinfo/boddaly/en/index.html (last accessed 11 October 2007).

Correspondence: School of Public and International Affairs, Virginia Polytechnic and State University, Architecture Annex (0113), Blacksburg, VA 24061, e-mail: gkearns@vt.edu (Kearns); Department of Geography, Queen Mary, University of London, Mile End Road, London E1 4NS, UK, e-mail: s.reid-henry@qmul.ac.uk (Reid-Henry). 